\title{
Chapter 18 \\ Mind and Brain: Toward an Understanding of Dualism
}

\author{
Kristopher G. Phillips, Alan Beretta, and Harry A. Whitaker
}

\subsection{The Views of Antiquity}

Starting two and half millennia ago in Greek antiquity and continuing to twenty-first century paradoxes, the story of dualism - the mind-brain problem - has many variations but retains some common themes. One of the earliest natural-philosophical investigations of the mind can be found in Homer's Iliad and Odyssey, epic poems thought to have been written in the seventh or eighth century BCE (Green and Groff 2003). While one assumes that Homer's main intention was to write heroic poetry and not to describe a psychological theory, his work nevertheless contains some interesting insights into the precursors of Western theories of mind. First, the Homeric Greeks appear not to have had a cohesive conception of mind nor of body (Jaynes 1990); there are no terms in Homer for words comparable to "soul" or "mind" or "thinking" or "perceiving" (Russo and Simon 1968). Instead in the Iliad and Odyssey we find terms such as psyche, thymos, menos, phrenes, and ate (Green and Groff 2003).

The word psyche appears in the first sentence of the Iliad. In both the Iliad and the Odyssey, psyche is compared to a "phantasm" or eidolon (Sandywell 1996). Like a phantasm, psyches are capable of haunting people after they have departed the body, as Patroclus haunts Achilles until Achilles will properly care for Patroclus' body. The psyche is ostensibly useless while inhabiting a living body; it does not appear to engage in cognition, emotion, or will. The psyche is the life-force of a thing and leaves the body when the body dies (Green and Groff 2003). After death,

K.G. Phillips $(\varangle)$

Department of Philosophy, Northern Michigan University, Marquette, MI, USA

e-mail: kristopher.g.phillips@gmail.com

\author{
A. Beretta \\ Department of Linguistics, Michigan State University, East Lansing, MI, USA \\ H.A. Whitaker \\ Department of Psychology, Northern Michigan University, Marquette, MI, USA
}


the vaporous, dispassionate psyche is exhaled and Hermes escorts it to Hades (Sandywell 1996). Two terms the ancient Greeks used to refer to what we now consider to be psychological processes are thymos and nous. Thymos, or thumos, is the source of emotion, sometimes with a quasi-intellectual aspect, and is strongly connected to motivation and will; its physical source is the diaphragm (Green and Groff 2003). The term thymos can be used to mean a particular impulse itself or, non-dualistically, the organ from which the impulse originated (Russo and Simon 1968). Thymos departs the body upon death, but does not go to Hades as does the psyche. Instead it appears to dissipate. Unlike the psyche, non-human animals are said to possess thymos (Green and Groff 2003).

The noos, or nous, is far more intellectual than the thymos. It was said to be located in the chest. The noos is somewhat similar to the mind or a product of the mind; it is not mentioned often in Homer's work, likely because his heroic poetry was more concerned with warriors than thinkers. Although the term noos cannot be translated literally as "the mind" it can refer to the organ of planning or to the capacity one has to plan or even to the plan itself. Avoiding or perhaps simply uninterested in a dualistic account, Homer does not distinguish between these uses; which one is intended at any given point is left for the reader to discern from context (Russo and Simon 1968).

Two other Homeric psychological terms are menos and ate. Menos is similar to thymos, but carries with it a more narrow range of application: menos is a divinely caused surge of battle prowess for a warrior who is on the verge of giving in to fatigue or despair on the battlefield, while thymos applies to the source of emotions generally. Ate is a kind of madness, and, like menos, often has a divine cause. For instance, when Agamemnon eventually returns the slave girl to Achilles, Agamemnon says his action comes from an ate caused by Zeus. In Homer's time, attributing mental states to external forces such as the gods, was not uncommon. It was not until sometime after Homer (perhaps 650-600 BC) that people began to write as though they were self-responsible for their mental states (Green and Groff 2003).

It is interesting to note that in the Homeric epics, it is possible for a person to converse with the thymos or phrenes almost as one would speak with another person. In the Odyssey, Odysseus engages in what might first appear to a modern reader to be a soliloquy about the perils of being lost at sea. As the apparent soliloquy continues, it becomes clear that Odysseus is not speaking to himself, but is instead engaging in a conversation with his thymos (Russo and Simon 1968). One could argue that a character in a Homeric epic does not engage in any activity in isolation; he is always in the presence of his thymos, menos, ate, and so on. An Homeric character's actions are not entirely his own - his hand can be stayed or his mind changed by the intervention of a god. Keeping these terms and concepts in mind, we can begin to frame a Homeric model of the mind, defined as follows (Russo and Simon 1968).

- Mental activity is represented as an exchange between personified concepts such as the thymos.

- Mental activity can be started by forces external to the person, such as a god or another person. 
- There is no obvious distinction between organs, the activity of the organ or the products of the activity of the organ.

- Mental activity is comprehensible and visible.

- The "self" is defined in a series of exchanges with others.

Thales, the earliest of the pre-Socratic thinkers averred, 'All things are full of gods'. ${ }^{1}$ Indeed it has been argued that for these early thinkers the entire natural world was alive and vital. ${ }^{2}$ How 'mind', 'spirit' or 'subjectivity' was related to matter, let alone the body or brain, was not a problem, it was simply a state of affairs. Yet the way in which they were 'attached' differed substantially between the different schools of pre-Socratic philosophers. One might presume, on the basis of the fact that mind-body interaction was taken as obvious, that the problem of substance dualism hardly intruded into the work of the greatest natural philosopher of the ancient world, Aristotle. Of course, such a suggestion requires some support, and a cursory discussion of other views is in order before we consider the Aristotelian view. Aristotle's approach can and we think, should, be understood largely as a response to the views of those that came before him. ${ }^{3}$

The pre-Socratic view that likely most influenced Aristotle's own views (and happens to be in some ways similar to the views of the seventeenth Century philosopher René Descartes ${ }^{4}$ ) belongs to the Pythagoreans. A striking departure from the hero myths of the Iliad and the Odyssey, Pythagoras is said to have had his followers study the work of an Asian-influenced Greek philosopher-poet by the name of Pherecydes, who maintained that the fear of death is unfounded since we survive the death of our earthly bodies and experience a rebirth in different bodies. The purpose of life, the Pythagoreans thought, was to prepare the soul for a final separation from material bodies in order to make the journey "home" to the ethereal plane. The nature of the soul, according to the Pythagoreans, was an immortal, immaterial divine entity that was roughly mathematical in nature (see Aristotle, De Anima I; Apostle and Gerson 1991). Himself a mathematician, Pythagoras noticed that the truths of geometry were not perfectly manifested in the ever-changing material/sensible world. Indeed, such truths were found only deep in the soul. The sensible world was an imperfect image of the divine world found within the soulfor instance, harmony found in music represented the kind of harmony that the soul was capable of when it finally reached the divine-world.

Pythagorean metaphysics is a complicated business, but for our purposes we can focus on that which made its way to Plato, and from Plato to Aristotle. The kind of

\footnotetext{
${ }^{1}$ Thales, as reported by Aristotle (De anima, 411a7); in Kirk and Raven 1971, 94.

${ }^{2}$ Frankfort and Frankfort 1949, 14: 'primitive man simply does not know an inanimate world.... The world appears to primitive man neither inanimate nor empty but redundant with life...'.

${ }^{3}$ See, for example (Apostle 1969), Metaphysics A, wherein Aristotle critically surveys the views of his immediate predecessors.

${ }^{4}$ It is worth noting that while the spirit (so to speak) of the Pythagorean view in some ways parallels the spirit of the Cartesian view, there are important differences in both the physics and metaphysics that inform the views.
} 
dualism present in the Pythagorean conception of the world was what we will here call a "form-matter dualism." According to Pythagorean metaphysics, the world and everything in it is made up of various ratios of peras (form) and apeiron (matter). It is from this dualism of form and matter that we can make sense of the soul's nature. For the Pythagoreans, the soul was made up of "the first tetractys" (the numbers, 1, 2, 3 and 4, which together add up to the "perfect number," or 10). The body, then, was composed of the point (1), the line (2), the plane (3) and the solid (4), which are the geometric correlates of the numbers. The soul possessed the powers of intellect, inferential knowledge, belief, and sensation. This seems to be the one of the first times that the soul was equated with what we now take to be the mind $^{5}$ and is a view that Descartes will champion much later. What should be noticed is that despite the importance of the separability of the soul from the body, their interaction is taken as a basic assumption. That there is a physical world and that it correlates to the mind can be accounted for, according to a Pythagorean, mathematically, as the correlate between ethereal number and its geometric manifestation. For them, this seems to suffice by way of an explanation.

Plato's view regarding the soul can be seen as a systemization of the Pythagorean form-matter dualism, incorporating the contributions of Heraclitus and Parmenides (Duerlinger 2005). Plato's account is notably less mathematical in nature than his Pythagorean predecessors, but the account of soul is strikingly similar. The soul itself is immortal, and this is guaranteed by the very essence of it (see Plato's Phaedo; later Aristotle defends Plato's approach to proving the immortality of the soul in Posterior Analytics). The soul, Plato famously argues, has three different parts: the intellectual, the spiritual, and the appetitive (Republic IV) (Hamilton and Cairns 1961). Each part plays an important role in giving life to the body. The appetitive keeps the body alive but tends to be somewhat unruly; the spiritual seeks honor, glory, and is the source of the passions; the intellectual is charged with the role of keeping the other parts of the soul in check - it does all of the heavy lifting, so to speak, with regard to reasonbased activity, reflection, and so on. Plato suggests in the Phaedo that the soul is most like the forms - that is, ethereal, timeless, immortal, and the object of true wisdom. In Plato's Timeaus it is argued that "tiny nails" connect the body and soul, a view that is reiterated, albeit metaphorically, in the Phaedo (Hamilton and Cairns 1961). Still, such an account of the fastening of the soul to the body fails to provide an illuminating answer to how the form and matter interact.

In Physics I 9, Aristotle attributes the view to Plato that mind and body are essentially different, and thus cannot interact (Apostle 1966). Furthermore, in Metaphysics A, Aristotle criticizes Plato for never offering an account of how the forms are able to interact with the sensible world (Apostle 1969). This point is important for several reasons. First, we see here the introduction of the notion of the essence of a thing. Essentialism plays an important role in Aristotelianism and the Scholasticism that dominated Western thought for over a thousand years after Aristotle; some notion

\footnotetext{
${ }^{5}$ Some scholars maintain that the accompanying creation doctrine is what Plato presents in his dialogue Timaeus. Others, Duerlinger (2005) e.g., think that Plato himself adopted a view very similar to this Pythagorean view.
} 
of essentialism even plays a role in Cartesian arguments for substance dualism. Second, understanding form-matter dualism is crucial for Aristotle's hybrid account, wherein Aristotle collapses the Platonic parallel form and matter worlds into one. Finally, this parallelism of form and matter might be seen as a precursor to Leibniz's famous doctrine of pre-established harmony - wherein the mind and body never actually interact; the universe is merely set up in such a way that the order of mental events directly parallels the order of the physical thus making it appear as if physical and non-physical beings can interact.

All of these are more spiritual and/or philosophical accounts of the mind than they are scientific (although the distinction as we know it now between philosophy and science is a rather new one, relatively speaking). In Aristotle's work we find a view that, while still very far from current science, more closely squares with what we take to be the dominant approach today; his naturalistic approach is at least much closer to what we understand as scientific than those views that incorporate separate insensible worlds and the doctrine of rebirth. Indeed, "If, then, one means by "identity theory" simply the contention that what we call mind and its manifestations are not separable from the body, surely Aristotle... subscribed to this theory" (Matson 1966, 93). Although Aristotle was Plato's student and thus inherited much of Plato's metaphysical baggage, an important difference between the two is that, while Plato did not seem to think that form and matter could interact (or at least did not have a plausible account of such interaction), Aristotle thought that all they did was interact. In fact, in Aristotelian terms, form cannot exist without matter, and matter cannot exist without form. ${ }^{6}$ For Aristotle, the form provides the essence, or the nature of the thing, while the matter provides the physical stuff to be made into that thing. For example, what makes a tree an oak tree rather than a cow is that the physical stuff that makes up the tree possesses the form of an oak tree. We can come to know the features or characteristics of that tree by coming to know the features that define what it is to be an oak tree.

This is relevant to Aristotle's notion of the human soul. What kind of form that matter takes on will directly impact the nature of the mind present in the being who exhibits that form. Substantial forms, as Aristotle calls them, are the soul, and different kinds of souls possess different parts, depending on what kind of form it is. There were three kinds of souls, those of plants, those of all animals including us and those specifically reserved for humans. In many cases the form does not provide for a soul, and thus there is simply no mind. Rocks, for example, do not have minds in the sense that we now think about it (although Aristotle does talk about rocks "wanting" to return to the earth, or fire "trying" to make it back to the sun because these are their natural places). Like those before him, Aristotle maintained that the soul was what gave life to a creature. And like Plato before him, Aristotle thought that the soul was divided into parts. Depending on the kind of soul a being possesses, it may have some or all of the following parts: [1] the reproductive/nutritive part of the soul (present in all living beings) which serves to reproduce more beings like it as well as to

\footnotetext{
${ }^{6}$ There is one notable exception to this general rule: God. According to Aristotle, the divine being is form itself, without matter. See, Metaphysics $\Gamma, \mathrm{Z}, \mathrm{H}$ and $\Lambda$.
} 
nourish the body, [2] the sensitive-imaginative part of the soul (present only in animals) is physically located in the sense organs of a living thing allowing for a creature to take in information about the world around it and to react. Do not let the term "imaginative" fool you, however; this refers not to flights of fancy, but rather to the ability to reproduce mental images of those sensory experiences taken in the present or past. [3] Next is the desiderative-locomotive part of the soul. This part of the soul (present only in animals, including human animals) gives beings the ability to desire pleasurable sensations, and to seek to avoid those sensations that cause discomfort; it also allows for the being to move around in an attempt to pursue or avoid such stimuli. [4] Finally, the intellective part of the soul (which exists only in humans) serves as the power of the soul to engage in rational reflection. The Aristotelian conception of the soul is rather directly reflected in the first systematic efforts to establish these functions in the brain, medieval cell doctrine (see Whitaker 2007).

For Aristotle, even though the soul has different parts, it is numerically single, albeit spread out throughout the body. The sensitive portions of the soul actually exist in the sense organs and as such, it may appear that Aristotle is the closest of the Greeks to modern-day physicalist accounts of the nature of the mind. ${ }^{7}$ However, such an assumption is not warranted. Aristotelian metaphysics are weird, and despite the actual physical location of the mind/soul in the body, there is still an important kind of dualism present in Aristotle's work. At the very least, there remains a form-matter dualism (nearly all things are composites of form and matter); there is still an important distinction between the material that makes a thing up (the material cause), and that which makes it what it is essentially (the formal cause). So despite Aristotle's proclivity for naturalism, and the collapsing of the patently dualistic world-view of Plato and the Pythagoreans, there still exists an important dualism in Aristotelian natural philosophy.

Still, the dualism present in the Aristotelian system is not obviously the kind of dualism philosophy professors teach to introductory students today. The kind of dualism taught in philosophy courses today more closely resembles developments derived from Renaissance philosophers (notably Cartesian substance dualism, or the more recently developed property dualism). Matson (1966) has argued that such a conception of dualism is entirely foreign to all the Greeks, and that maybe they (the Greeks) had the right idea. If Matson is correct, there is something instructive about the kind of dualism present in Aristotle's natural philosophy, even though that dualism is radically different from how we think of it today. If Aristotle and his Greek peers never considered the mind-body problem (or soul-body problem) in the way that we do today, it is not hard to see how something like his conception of the soul can lead to the conception we do grapple with today.

The break-up of classical civilization in the fifth century CE that ushered in the so-called 'dark ages' into most of Europe was shortly followed by the emergence of a brilliant civilization in the Islamic Middle East. Although a great deal of the Islamic 'golden age' was based on Arabic translations of the major works of Greek

${ }^{7}$ For a defense of the view that Aristotle did not consider the body and soul separate in any sense, see Matson 1966. 
antiquity, it also saw an independent development of early experimental science. One thinks of Ibn al-Haytham's (known as Alhazen in the west) optics ${ }^{8}$ as well as labor-saving technologies, especially those powered by water. With the postCrusades' translation into Latin of the major part of Arabic learning in the twelfth century et seq, Arabic developments in natural philosophy, medicine and technology were (re-) introduced into Europe. Concomitantly, during the later Middle Ages a reorientation away from the things of the next world towards the things of this world, slowly accelerated. Technologies based on human and animal muscle power slowly gave way to technologies based on wind and water power. ${ }^{9}$ The concept of the inorganic, of efficient rather than final causes, increasingly took hold.

\subsection{The Medieval Perspective}

Depending on our personal convictions, today we may consider mind to be something distinct from soul (of course not everyone would speculate on either the existence or the contents of the soul). But for the medieval and Renaissance thinkers, mind and soul were intertwined and man's soul was divided into parts roughly following the Aristotelian model, the Platonic model or a creative alternative. The diagram makers who represented medieval cell doctrine sometimes represented a three-part soul (Dryander, Reisch-Brunschwig) and sometimes a five-part soul (a translation of Avicenna); sometimes the parts were divided in two, creating a six-component model (the 1503 Bologna drawing, Albertus Magnus) and sometimes each part represented a single function (see Whitaker (2007) for discussion). What concerns us here is the rational part of the soul: it comprises both of the other kinds of soul, but it adds reason and is not shared with plants or other animals. Rational soul, in all of its complex interpretations, is the nearest anyone came to the contemporary notion of mind (see Lewis 1964, pp. 153-165).

Medieval scholars recognized that there needed to be some means for (rational) souls, which were considered immaterial, to interact with bodies. And they were not shy about proposing solutions. The picturesque solution presented by Alanus ab Insulis, a twelfth century French thinker and poet, was that "the soul is fastened to the body gumphus subtilibus, "with tiny little nails"” (cited in Lewis, p. 60 as from Plato's Timaeus, 43a).

It was commonly believed that some sort of 'subtle gumphus' was required to bind body and soul together and if it was not going to be 'tiny little nails', then it had to be some other entity. As Lewis, put it, "this tertium quid, this phantom liaisonofficer between body and soul, was called Spirit or (more often) the Spirits... The spirits were supposed to be just sufficiently material for them to act upon the body, but so very fine and attenuated that they could be acted upon by the wholly immaterial soul" (p. 166-7). For example, in Timothy Bright's sixteenth century Treatise of

\footnotetext{
${ }^{8}$ Al-Haytham's Optics was published about 1025 CE; see Sabra $(1983,2002)$.

${ }^{9}$ White 1963 . White gives a number of reasons for the development of labour-saving technologies in medieval Europe, not least 'the spiritual repugnance of subjecting anyone to drudgery' (p. 291).
} 
Melancholy (Bright 1586), the spirits are, "a true love knot to couple heaven and earth together; yea, a more divine nature than the heavens with a base clod of earth", so that the soul is "not fettered with the bodie, as certaine Philosophers have taken it, but handfasted therewith by that golden claspe of the spirit" (Lewis, p. 167).

The other attempt to ease the ever-mounting worries about how the mind and body interact is the notion of 'animal spirits' which, as we've noted, was the medieval cell doctrine solution, particularly popular from the fourteenth to the sixteenth centuries; this was the model that René Descartes chose to use. Lewis, a scholar of medieval literature and thought who rejoices in many of the peculiarities of the medieval worldview, emphatically draws the line here: "This doctrine of the spirits seems to me the least reputable feature in the Medieval Model. If the tertium quid is matter at all (...) both ends of the bridge rest on one side of the chasm; if not, both rest on the other" (p. 167).

The difficulties with substance dualism slowly came into focus during this period. At least from the time of Galen and possibly before, the status of these 'animal spirits' present in the brain's ventricles and (most believed and Descartes famously drew) in the nerves and blood vessels, was to say the least, ambiguous. Were they merely messengers from the 'soul' lodged in the 'marrow' of the brain or did they possess psychic qualities of their own? Vesalius, in the mid-sixteenth century, began to suspect that the watery fluid in found in the ventricles was no more than, precisely, a watery fluid, and speculated (in print at least) no further. ${ }^{10}$ It was only with Descartes in the seventeenth century, inspired by the Copernican/Galilean revolution in natural philosophy toward which the long centuries of the medieval period had been headed, that a final and complete separation of mind from body occurred. Descartes' L'Homme (Cottingham et al. 1984) treated the animal as an 'earthen machine', animal spirits as no more than the spirits one might find sold in any bar, while mind became, in Gilbert Ryle's phrasing, 'a ghost in the machine' (Ryle 2002).

The medieval view of the mind-body problem is distinctly unsatisfying to the modern way of thinking, notwithstanding its representation of a componential mind with distinct geographic locations in the brain. With that background in mind, let us now turn to Descartes and his sharply drawn distinction between mind and body, without the complication of a tripartite soul and the mediation of a range of spirits, but crucially, with a clear guiding principle regarding the nature of 'body'. This clarity will make it far easier for us to see why the Cartesian formulation of the mind-body problem is not the problem facing modern scientific inquiry.

\subsection{The Cartesian Formulation}

Cartesian dualism is a rather clear concept: Mind and soul are one and the same substance, it is immaterial, and the essence of it is thought. Indeed, in a departure from the Aristotelian conception, Descartes denied that, properly understood, the "soul" could exist in anything other than a human. He wrote, "I do not admit that

${ }^{10}$ Vesalius 1998-2009, Book VII, Chapter 1, p. 624. 
the powers of growth and sensation in animals deserve the name 'soul', as does the mind in human beings. This common view is based on ignorance of the fact that animals lack a mind" (letter to Regius, May, 1641) (Cottingham et al. 1991). On the other hand, physical bodies are a completely different substance, the essence of which is mere extension. Neither substance requires the other to exist (the mind can and eventually will exist entirely without physical body and vice versa). Cartesian physics, following the Aristotelian dictum that "nature abhors a vacuum," maintained that the universe is a plenum, and as a result of this, only mechanical forces can and do move physical bodies. Perplexingly, on the Cartesian model the mind has the ability to move the body without apparent direct mechanical contact. Descartes famously 'solved' this problem by proposing that the pineal gland is the gateway from the body to the soul (and the soul to the body).

Descartes knew what body (or the physical, or matter, or material substance) was. It was res extensa, stuff that occupied, or had extension in space. He also knew how motion of such stuff could be effected. Motion had to be effected by direct contact with other stuff that occupied space. These two key properties of bodies sustained his mechanical view of the natural world; nature could be understood in just the way we might understand how a machine works. Just as Descartes' contemporaries could appreciate the action of springs, cogs, and wheels that bring about the motion of the hands of a clock, so they could appreciate that the planets are pushed around the sun by a celestial fluid, and so they could appreciate all natural phenomena. It is worth noting that the celestial fluid was no different in kind from any other physical stuff. All of the stuff that existed in the natural world had the same essence, extension.

All except mind. The essence of mind, Descartes maintained, was thought alone. From this, Descartes seemed to know that it did not occupy space and thus could not be subject to mechanical laws. Mind could plainly bring about motion (I decide to move a finger, and I do), but it could not do so by contact mechanics. It is this characterization that makes most clear the mind-body problem. The contrast between body and mind in this formulation is thus sharply drawn. Body is everything extended, and everything behaves the way a machine behaves, everything except mind. So, mind-stuff and body-stuff must be distinct substances. This sharp distinction is what gives the Cartesian mind-body problem its crispness. Its wide acceptance is in large part due to its clarity, no doubt, but also to its consonance with our commonsense intuitions. The world was just the way it seemed to be; it had objects in it, bodies that moved in ways prescribed by the laws of mechanism, that is, via direct contact.

But the clarity of the distinction between mind and body is a dual-edged sword. The clarity of the distinction and the epistemological argument for the distinction (in Descartes' Sixth Meditation) provided a clear challenge. Princess Elisabeth of Bohemia articulates the worry that becomes apparent when considering Cartesian mind-body interaction most acutely in her correspondence with Descartes. It is worth quoting in full. She says,

I beseech you tell me how the soul of a man (since it is but a thinking substance) can determine the spirits of the body to produce voluntary actions. For it seems every determination of movement happens from an impulsion of the thing moved, according to the manner in which it is pushed by that which moves it, or else, depends on the qualification 
and figure of the superficies of the latter. Contact is required for the first two conditions, and extension for the third. You entirely exclude extension from your notion of the soul, and contact seems to me incompatible with an immaterial thing. That is why I ask of you a definition of the soul more particular than in your Metaphysic - that is to say, for a definition of the substance separate from its action, thought (Letter to Descartes, 6 May, 1643, in Atherton (1994)).

Mind should not be able to move anything physical and yet it does. There can be no 'tiny little nails' to solve the problem, no superfine spirits, no hocus-pocus of the Medieval sort, but a mystery that is a consequence of a mechanical view of the world. Descartes never really had a clear or satisfactory answer for Elisabeth. Famously, he maintained that the soul is connected to the body at the pineal gland. ${ }^{11}$ How exactly it is that the soul interacts with the pineal gland Descartes tried to explain to Elisabeth, and plenty of scholars have since tried to make sense of his response to her. Unfortunately, like Plato before him, the best he could come up with was something of a hand-waving analogy and references to simple and ultimately unsatisfactory ideas.

Newton's gravitational force shattered the mechanical worldview. A force does not occupy space and it moves objects without direct contact. So, the notion of body that stood in clear contrast to mind in the Cartesian formulation of the mind-body problem faced a new challenge with this new physical theory. According to the Cartesian Programme, the mind was of a fundamentally different kind than bodies. Despite the difficulty of reconciling how the mind interacted with the body, it was clear that it did. We could examine and understand mind and body separately; each one existed in a different domain of inquiry. When forces were introduced into physical theories, the hard and fast distinction between mind and matter was lost, and with it, its usefulness. In the new physics, body could be res extensa or not, and so the contrast with mind, which previously was the only thing that was not res extensa, had been consigned to oblivion. Res extensa itself was not possible without the basic forces. As Priestley observed: take away the forces, and there would be no solid objects, not even an atom, as everything would be dispersed and there would be nothing left for the imagination to fix upon.

The Cartesian mind-body problem was deflated because 'body' had ceased to have the character upon which the problem was premised (it was also challenged on quite different grounds by La Mettrie (1748/1996) and Locke (1690/1975)). Indeed, since the new science was dealing in forces, vacuums, and other kinds of things that were 'impossible' given the Cartesian world-view, there was no means of maintaining the distinction between material and immaterial 'substances.' That is, built into the new 'physical' science were theoretical entities that did not occupy space and could effect movement across a vacuum without direct contact, eliminating any clear divide between mind and body. To put the point succinctly, the realm of what counted as physical, and thus within the purview of the physical sciences (or "natural philosophy") was anything that entered theory and that evidence indicated was real.

\footnotetext{
${ }^{11}$ See, for example, Letter to Meyssonnier, 29 January, 1640; to Mersenne, 1 April, 1640; and to Mersenne, 30 July, 1640.
} 


\subsection{What Does Mind-Body Dualism Mean Now?}

It's a matter of some perplexity why the expression Cartesian dualism continues to have the sort of currency that suggests that the Newtonian revolution never occurred and that we are still basking in the psychological luxury of nature appearing to be just like our common sense dictates it should be. The once principled and clear divide between mind and body lost much of its justification once the consequences of forces were taken on board. So, it does not seem reasonable that anyone today would subscribe to Cartesian dualism (where the view is understood as a scientific hypothesis regarding the essential and complete distinction between mind and body). However, the mind-brain problem is very much alive and well; that it remains a serious and interesting problem is well articulated in the delightful book Mind, Brain and the Quantum: the Compound "I" by Michael Lockwood (1989).

And yet, although we plainly have no reason to create a physical-nonphysical 'substance' divide, many proceed as if such a divide obviously exists. To illustrate this, we will take some examples from highly accomplished scholars who care deeply about language-brain relations. Pulvermüller (2002), for instance, is concerned about the failure, as he sees it, of linguistics to translate itself into a plainly physical account, one based on neurons. Instead, recalcitrant linguists appear to think that "language theories must be formulated in an abstract manner, not in terms of neuron circuits", excluding "explicit reference to the organic basis" of language; "for a scientist this may be difficult to understand". This incomprehensible "linguistic mentality" is comparable to that of a "scholar who studies stars but refuses to speak about their component substances and driving forces". What is called for are "translations between the language of linguistic algorithms and that of nerve cells"; "a language theory at the neuronal level is required", but linguists continue to neglect this need; "it is not enough to provide abstract descriptions of language phenomena; it is also necessary to spell out possible language mechanisms in terms of neuronal circuitry" (270-3). On Pulvermüller's account, linguistics has failed to reduce itself to purely physical matter. However, his allegations assume a qualitatively unwarranted divide. On the physical side, he does not question the failure to translate neural accounts into the structures and structural relations of linguistic theory; however, on the abstract side, he proclaims the failure to express theory in physical (neural) terms. Apparently, the physical side is more real or at the very least, has some privileged status that the abstract side lacks. We see the same view in many others who think about how the language-brain problem can be resolved. To cite another recent example, "language researchers who fail to embrace biological approaches will be increasingly left behind" (Margoliash and Nusbaum 2009, 510). Left behind! As the seventeenth century poet Henry Vaughn put it "They are all gone into the world of light / And [linguists] alone sit lingering here." What seems to worry these authors is that core linguistic proposals are made unconstrained by developments in neuroscience ("Neurobioogy and Neuroethology" op cit, 505). Evidently, it never occurred to them that they might equally register angst that core neurobiological proposals are made unconstrained by developments in 
linguistics. One side of the divide has been conferred a special status; this is what Noam Chomsky referred to as methodological dualism.

Yet we have seen that since Newton, such a simplistic divide has no justification. The 'physical', whatever that is, is not more real and has no privileged status at all; indeed, as argued in Beretta (2014) it has no useful status. All we have are phenomena in the world that present themselves to us, and we try to understand them as best we can; that is, we construct theories about them and test them. To the extent that these theories are currently not integrated with each other, we hope that one day our understanding will be such that integration will be possible. ${ }^{12}$ But the physicalsupremacy approach, a standard way of viewing the problem of language-brain relations, has its basis in a discarded model. The demand for physical explanation, and the attendant frustrations of those who divide the world up that way, as Pulvermüller, Margoliash, Nusbaum and many others continue to do, has many historical parallels, as we have seen (Beretta 2014).

In the light of the history of natural inquiry over the last few centuries, what are we to make of such concerns as Pulvermüller's? Recall his view that linguistics is unacceptable for devising its theories in an abstract manner, by which he means 'not in terms of neuron circuits', an approach that he judges would be difficult for a scientist to understand. However, physics, by all accounts, is a ghost field (as Kline (1985) puts it); that is, physics is so abstract that 'physical' has no useful meaning; linguistics is abstract, another ghost field, and so is neurobiology. Which is only to say what has become so abundantly clear since Newton that it is now commonplace: inquiry is governed by theories, however abstract, bizarre, absurd, etc., they may seem to be, so long as they agree with experiment, in other words, with our best attempts to acquire an understanding of aspects of nature. Thus, to assume that theory in one domain, which is allegedly not abstract, in some sense yet to be explained, has a privileged status over theory in another domain, requires justification; lacking any to date, the assumption is truly rather difficult to understand, let alone accept.

But perhaps what is meant when many scholars refer to dualism today is that there is a problem that we all face: how to unify our theories of mind and our theories of brain. No one, least of all the present authors, could argue with that. Lest one minimize the problem, however, we do realize that the theory-unification problem is an enormous challenge, the solution which some commentators (e.g., Nagel 1974; Chalmers 1995, 1996)) believe may be beyond us, or "if it exists, lies in the distant intellectual future" (Nagel 1974, 436). This is impossible to know, but it is a measure of the magnitude of the perceived challenge that it conjures up such pessimism among some of those who think deeply about the issues. It would

\footnotetext{
${ }^{12}$ There are a number of theoretical debates continuing in the philosophy of mind. Dating back to J.J.C. Smart's important (1959) paper "Sensations and Brain Processes," there is the view that seeks a theoretical reduction of paradigmatic mental states to brain states, just as we are able to reduce lightning to electrical discharges. More recently, Kari Theurer and John Bickle (2013) have revived something of a mechanistic approach to the reduction of the mental to the physical. Lockwood (1989) suggests that the existence of what we refer to as consciousness presents yet another challenge to the common-sense view of matter, just as does quantum theory.
} 
be misleading, however, to suggest that such pessimism is the dominant view in the relevant literature.

To return to our theory of language, mainstream linguistic theory makes no mention of neurons. But it explains a vast range of phenomena more or less well, as the evidence is more or less compelling. That just happens to be the best anyone has been able to come up with, where it was possible to make progress. Where we do not seem to be able to make progress is by looking for inspiration in theory construction from what we know about brains. Of course, everyone would hope that one day, if we understand more and more about language and more and more about brains, we will be able to see how the two theories can constrain each other. This is perhaps where many scientists would situate their views. But if we take the further step of dictating how theory construction should proceed, then our notion of dualism is far from innocuous and it is also unwarranted. So far as we know, prior to Maxwell, no one berated those who tried to understand electricity for failing to frame their theories in terms of light or of magnetism, or vice-versa. The assumption that one side of a theoretical divide has to conceive itself in terms of the other side of the divide apparently applies uniquely to mind-brain relations; that is, it is a relic of a defunct version of dualism that serves no useful purpose at all (see Chomsky 1995 for discussion).

Versions of dualism persist, not only in discussions that reject linguistic theory as "brain averse" (Churchland's 2002 term), but also in discussions of "eliminative materialism' and of qualia (Chalmers 1995), for example. We think that such views presuppose that there is some serviceable concept of 'physical' to which one can appeal. It would be interesting to know what characterization of 'physical' modern apologists for dualism have in mind. It would have to be something that can cover all objects that have extension, the fundamental forces (gravitational, electromagnetic and nuclear), electric and magnetic fields, quantum electrodynamics, and so on. Thus, perhaps all that can possibly be intended by the modern usage of 'dualism' is that we have our best theory of some aspect of mind on the one hand and our best theory of brain on the other and that they do not seem to share any properties. If so, then that is probably a fair characterization of where we are at this juncture in our intellectual history. But if all that is meant by 'physical' is the best that human minds have been able to come up with, that is, best theories, then no principled divide with the mental can be at issue, as we have argued; what is then at stake amounts to nothing more than a familiar, but very complex, theory-unification problem. Thus, we can point to our theory of brain and we can believe that the brain does the mind's work and wish that our theory of mind could match our theory of brain. But it doesn't just happen because we wish it to, and there is no point in belaboring a theory of some aspect of mind because it does not frame itself around what we know about brains.

In this chapter, we have provided a glimpse of the differing views of dualism from antiquity to the present. We cannot possibly do justice to the full complexity of the issues that any discussion of dualism gives rise to. Rather than attempt to go into every nook and cranny of 'if' and 'perhaps' and 'but', we have instead presented a particular view (one that readers might have encountered elsewhere, for example, 
in the writings by thinkers such as the mathematician, Morris Kline, or the linguist, Noam Chomsky); this view rejects dualism on the grounds that there is no sustainable mental-physical divide since we lack any useful concept of 'physical' and have not had one since Newton proposed action at a distance. Inquiry into mind-brain relations, on this view, is a problem of unifying theories, not a problem of reducing mind to matter, or any other formulation of the problem that seeks to salvage dualism. We hope that this at least provides a clear perspective that might generate worthwhile discussion.

\section{References}

Apostle H (1966) Aristotle's metaphysics, translated with commentaries. The Peripatetic Press, Grinnell

Apostle H (1969) Aristotle's physics, translated with commentaries. The Peripatetic Press, Grinnell Apostle H, Gerson L (1991) Aristotle: selected works, 3rd edn. Peripatetic Press, Grinnell

Atherton M (1994) Women philosophers of the early modern period. Hackett Publishing, Indianapolis

Beretta A (2014) Joseph Priestley: an instructive 18th century perspective on the mind-body problem. In: Smith C, Whitaker H (eds) Brain and mind: essays in the history of neuroscience, Springer series in history, philosophy and theory of the life sciences. Springer, New York

Bright T (1586) A treatise of melancholie, containing the canvases therof, and reasons of the strange effects it worketh in our minds and bodies: with the phisicke cure, and spirituall consolation for such as haue thereto adioyned an afflicted conscience. Thomas Vautrollier, London

Chalmers D (1995) Facing up to the problem of consciousness. J Conscious Stud 2(3):200-219

Chalmers D (1996) The conscious mind. Oxford University Press, Oxford

Chomsky N (1995) Language and nature. Mind 104:1-61

Churchland PS (2002) Brain-wise: studies in neurophilosophy. MIT Press, Cambridge, MA

Cottingham J, Stoothoff R, Murdoch D (1984) The philosophical writings of Descartes vols I, II. Oxford University Press, Oxford.

Cottingham J, Stoothoff R, Murdoch D, Kenny A (1991) The philosophical writings of Descartes, vol 3. Oxford University Press, Oxford. Letter to Meyssonnier: (CSMK, p. 143); Letter to Mersenne: (CSMK, p. 145); Letter to Regius (CSMK, p. 181)

De la Mettrie JO (1748/1996) Machine man. In: Thomson A (ed) La Mettrie: machine man and other writings. Cambridge University Press, Cambridge, pp 1-39

Duerlinger J (2005) Plato's Sophist: a translation with a detailed account of its theses and arguments. Peter Lang Publishing, New York

Frankfort H, Frankfort HA (1949) The intellectual adventure of ancient man: an essay on speculative thought in the ancient near East. Penguin, Baltimore

Green CD, Groff PR (2003) Early psychological thought: ancient accounts of mind and soul. Praeger, Westport

Hamilton E, Cairns H (1961) The collected dialogues of Plato including the letters. Princeton University Press, Princeton

Jaynes J (1990) The origin of consciousness in the breakdown of the bicameral mind. Houghton Mifflin, Boston

Kirk GS, Raven JE (1971) The pre-socratic philosophers: a critical history with a selection of texts. Cambridge University Press, Cambridge

Kline M (1985) Mathematics and the search for knowledge. Oxford University Press, New York

Lewis CS (1964) The discarded image: an introduction to medieval and renaissance literature. Cambridge University Press, Cambridge 
Locke J (1690/1975) Nidditch PH (ed) An essay concerning human understanding. Clarendon Press, Oxford

Lockwood M (1989) Mind, brain and the quantum: the compound "I". Basil Blackwell, Oxford

Margoliash D, Nusbaum HC (2009) Language: the perspective from organismal biology. Trends Cogn Sci 13:505-510

Matson W (1966) Why isn't the mind-body problem ancient? In: Feyerabend P, Maxwell G (eds) Mind, matter and method: essays in philosophy and science in honor of Herbert Feigl. University of Minnesota Press, Minneapolis

Nagel T (1974) What is it like to be a bat? Philos Rev 83:435-450

Pulvermüller F (2002) The neuroscience of language: on brain circuits of words and serial order. Cambridge University Press, New York

Russo J, Simon B (1968) Homeric psychology and the oral epic tradition. J Hist Ideas 29(4):483-498

Ryle G (2002) The concept of mind. University of Chicago Press, Chicago

Sabra AI (ed) (1983) The optics of Ibn al-Haytham, books I-II-III: on direct vision. The Arabic text, edited and with introduction, Arabic-Latin glossaries and concordance tables. National Council for Culture, Arts and Letters, Kuwait

Sabra AI (ed) (2002) The optics of Ibn al-Haytham. Edition of the Arabic text of books IV-V: on reflection and images seen by reflection. 2 vols. The National Council for Culture, Arts and Letters, Kuwait

Sandywell B (1996) The beginnings of European theorizing: logological investigations. Routledge, New York

Smart JJC (1959) Sensations and brain processes. Philos Rev 68:141-156

Theurer KL, Bickle J (2013) What's old is new again: Kemeny-Oppenheim reduction in current molecular neuroscience. Philos Sci 17(2):89-113

Vesalius A (1998-2009) On the fabric of the human body (trans: Richardson WF, Carman JB), 5 vols. Norman Publishing, San Francisco/Novato

Whitaker HA (2007) Was medieval cell doctrine more modern than we thought? In: Cohen H, Stemmer B (eds) Consciousness and cognition: fragments of the mind and brain. Elsevier Science, London, pp 45-51

White H (1963) An anatomy of kinship. Prentice-Hall, Englewood Cliffs 